\title{
EXPERIMENTAL INFECTION OF MONKEYS WITH HERPESVIRUS SUIS (AUJESZKY'S-DISEASE VIRUS)
}

\author{
A. Baskerville aNd G. LLOYD \\ Microbiological Research Establishment, Porton, Salisbury, Wiltshire SP4 OJG
}

THE pathogenesis of herpesvirus infections of primates has recently received much attention because of the similarity to human herpesvirus infections and the serious nature of human infection with Herpesvirus simiae, the so-called " monkey B-virus". H. suis, usually known as Aujeszky's-disease virus (ADV) is serologically related to B virus and $H$. hominis, probably sharing a group antigen with these viruses (Sabin, 1934; Watson et al., 1967; Jentzsch and Wigand, 1969). ADV naturally infects many species of animal, particularly the pig, but not man or other primates; there is no serological evidence of human infection occurring even in those occupationally at risk (Jentzsch and Wigand, 1969). Jentzsch and Apostoloff (1970) went so far as to attempt experimental infection of human volunteers, without success. However, in monkeys, subcutaneous or intracerebral injection of the virus leads to a fatal encephalomyelitis (Hurst, 1933, 1936; Kersting and Kerekjarto, 1959) resembling B-virus infection in man.

Infection of primates with ADV may offer a useful system for the study of herpesvirus encephalomyelitis experimentally without undue risk to laboratory staff. Earlier work with this virus in monkeys was limited to infections produced by parenteral or intracerebral inoculation. The present study examines the pathogenesis of the infection and the excretion and distribution of the virus in the body after intranasal infection.

\section{MATERIALS AND METHODS}

Animals and experimental design. In two experiments, 24 adult grivet monkeys (Cercopithecus aethiops) and two squirrel monkeys (Saimiri sciureus), of either sex, were infected with virus, and four other grivets from the same original group of animals were kept as uninfected controls; none of them had pre-existing antibody to B virus. They were anaesthetised with ketamine hydrochloride (Vetalar, Parke Davis), given intramuscularly, before all handling procedures, including injection of virus, recording of body temperature and the taking of nasal and oral swabs.

The virus was the NIA-2 strain of ADV, supplied by Dr J. B. McFerran and grown as described previously (Baskerville, McCracken and McFerran, 1971). The inoculum dose for the grivet monkeys was $10^{7}$ TCD50 of virus suspended in $1 \mathrm{ml}$ of tissue-culture medium 199 containing $2 \%$ foetal bovine serum; $0.5 \mathrm{ml}$ was instilled into each nostril. The two squirrel monkeys received $10^{6} \cdot 5$ TCD50.

One to three monkeys were killed, by intracardiac injection of pentobarbitone sodium under general anaesthesia, daily for 11 days and on the 13th day after infection; three grivets and the two squirrel monkeys died naturally after 7-9 days. The four control monkeys were killed on days 1 to 4 . Necropsy was performed immediately after death on all monkeys, and tissues were taken for isolation of virus and histopathological examination.

Virus isolation. Nasal and oral swabs were taken, daily for 10 days after infection, from eight grivet monkeys; they were immediately expressed into $1 \mathrm{ml}$ of transport medium containing bovine serum albumin and lightly centrifuged to remove debris. From dead

Received 23 July 1976; accepted 24 Aug. 1976.

J. MED. MICROBIOL.—VOL. 10 (1977)

139 
monkeys, specimens were taken from the olfactory lobes, the mid-cerebrum, the caudate nucleus, thalamus, cerebellum, medulla and cervical spinal cord, the trigeminal and geniculate ganglia on both sides, the palatine tonsil, the parotids, the mandibular lymph nodes, the liver, the kidneys and the lungs. The tissues were homogenised by grinding with sterile sand, and $10 \%$ or $20 \%(\mathrm{w} / \mathrm{v})$ extracts were prepared in medium 199 containing $2 \%(\mathrm{v} / \mathrm{v})$ of foetal bovine serum, $0.1 \%(\mathrm{w} / \mathrm{v})$ of crystamycin, $2 \%(\mathrm{w} / \mathrm{v})$ of sodium bicarbonate and $1.4 \%(\mathrm{w} / \mathrm{v})$ of Hepes buffer. The homogenised tissue extracts and swab supernates were inoculated on to monolayers of Vero cells in Microtitre plates. The cultures were examined for the cytopathic effects (CPE) of ADV daily for 14 days, and any viruses isolated were identified by neutralisation with a specific anti-ADV antiserum prepared in pigs.

Serum-antibody tests. Serum was collected by cardiac puncture under general anaesthesia 5-8 days after infection and again on the 10th day. Serial two-fold dilutions were mixed with an equal volume of virus suspension containing $200 \mathrm{TCD} 50$, and incubated at $37^{\circ} \mathrm{C}$ for $1 \mathrm{~h}$. The mixtures were then inoculated on to Vero cells in Microtitre plates and the cultures were examined for CPE daily for 14 days.

Histopathological examination. Portions of brain, spinal cord, nasal conchae and nasal mucosa, palatine tonsil, tongue, larynx, trachea, lungs, heart, liver, spleen, kidneys, adrenal glands, small intestine and bronchial, mandibular and cervical lymph nodes were fixed in $10 \%$ buffered neutral formalin. After initial fixation, the larynx and nasal conchae were decalcified in Gooding and Stewart's fluid and again fixed in formalin. All the tissues were processed by standard methods and embedded in paraffin wax; $5 \mu \mathrm{m}$-thick sections were cut and stained with haematoxylin and eosin.

\section{Results}

\section{Clinical signs}

Clinical signs or changes in behaviour were not seen in any animal before the 7th day. These first appeared between 7 and 9 days in most cases, but occasionally not until as late as the 13th day. Illness started abruptly and was of short duration, lasting only 4-12 h. Some of the monkeys in the later stages of the disease showed a slight rise in body temperature to $103^{\circ} \mathrm{F}$ (the normal temperature for the group was $101^{\circ}-102^{\circ} \mathrm{F}$ ); the highest temperature recorded was $104 \cdot 6^{\circ} \mathrm{F}$. The earliest and most consistent sign of infection was excessive salivation, saliva drooling in large quantities from the lips and causing the hair of the chest and abdomen to become wet and bedraggled. Salivation was accompanied by continual licking of the lips and swallowing. At no stage of the infection were there any lesions in the mouth or on the skin. Neurological signs varied in kind and severity, but included repeated turning of the head and looking over one shoulder while sitting, and tremors and tonic spasms of the arms which resulted in the animal dropping food. These symptoms of incoordination progressed rapidly, over a few hours, to obvious ataxia with nystagmus and to opisthotonus and epileptiform convulsions. Three monkeys that reached this extreme state respectively 7,8 and 9 days after infection became comatose and died within $1-2 \mathrm{~h}$ without regaining consciousness. The two squirrel monkeys differed from the grivet monkeys in that both were found dead on the 7th day, less than $2 \mathrm{~h}$ after feeding, apparently normally, without showing any signs of disease; at necropsy, there was evidence of excessive salivation, but this must have been of extremely short duration.

\section{Necropsy findings}

There were no gross lesions in the brain or other organs of either the infected or the control monkeys. Histopathological changes were confined to the central nervous system and were present only in monkeys killed or dying after the 6th day. There was a non-suppurative meningoencephalomyelitis, localised to certain regions of the brain and affecting predominantly the grey matter. Areas consistently and severely affected were the caudate nucleus, internal capsule, putamen, area paraolfactoria, thalamus, and the tracts and nuclei of the fifth, seventh and ninth cranial nerves in the pons and medulla. The cerebral cortex 
was uncommonly involved, with only small lesions. The cerebellar peduncles, and rarely the cerebellar folia, showed only isolated perivascular cuffs or microglial foci. Damage was no more severe or extensive in animals killed or dying in the later stages of infection than in those dying earlier.

The lesions consisted of degeneration of neurones, ranging from chromatolysis to necrosis, diffuse and focal gliosis, and areas of parenchymal necrosis. This last feature was particularly evident in the caudate nucleus, area paraolfactoria and putamen. Intranuclear inclusion bodies were present in many neurones and glial cells, especially in areas of parenchymal necrosis and heavy cellular infiltration. Most were classical Cowdry type-A eosinophilic inclusions, but some were faintly basophilic and granular in appearance and occupied nearly all of the nucleus. Perivascular cuffing by lymphocytes and macrophages was prominent although the cuffs were rarely more than three cells thick; this was only occasionally present in the cerebral cortex and cerebellum. The leptomeninges were infiltrated locally by small numbers of lymphocytes and macrophages, the amount of reaction varying considerably in different areas.

In the spinal cord, lesions were confined to the cervical and thoracic regions, and consisted of a few small perivascular cuffs and microglial foci, distributed approximately equally between grey and white matter, with degenerative changes and necrosis of some neurones in the dorsal and ventral horns. There was also some localised infiltration of cells into the meninges.

\section{Virus isolation}

Grivet monkeys. Virus was not isolated from any of the nasal swabs, collected daily for 10 days from eight monkeys. Only a single oral swab was positive, and this was taken on the 7th day from a monkey that had not yet developed signs of illness; the titre of virus in the swab extract was $10^{2 \cdot 6}$ TCD50 per ml.

At autopsy, virus was isolated only from the central nervous system, and from only three of the 18 monkeys examined. Virus was isolated only from the medulla of one of these, killed on the 4th day (calculated concentration of virus in the medulla, $10^{3.5}$ TCD50 per $\mathrm{g}$ ); from only the caudate nucleus of the second, killed on the 8 th day $\left(10^{3 \cdot 8}\right.$ TCD50 per g); and only from the mid-cerebral cortex of the third monkey, killed on the 10th day (104 TCD50 per g). The other portions of brain and the other organs and tissues examined from these three monkeys were negative for virus isolation.

Squirrel monkeys. Virus was more readily isolated from the brains, as well as from some other tissues, of the two squirrel monkeys. The results are shown in the table.

\section{Antibody responses}

Neutralising antibody was not detected in the serum of any of the four monkeys examined after 5-8 days, or of the one examined after 10 days.

\section{Discussion}

ADV caused a rapidly fatal disease in the monkeys after intranasal infection. Salivation and neurological disturbances were constant features, but fever was generally mild or absent. These symptoms were similar to those obtained by earlier workers with intracerebral and parenteral inoculation (Hurst, 1933, 1936; Kersting and Kerekjarto, 1959). It is interesting that pruritus, which is the characteristic clinical sign of ADV infection of carnivores and ruminants, was not observed in the monkeys in either the present or the earlier studies. The incubation period of 7 to 13 days is similar to that reported after parenteral infection, though longer than after intracerebral (Hurst, 1933, 1936). The very short duration of the illness and the failure to detect neutralising antibody in any of the monkeys suggests that this is a true incubation period and not merely a variable survival time after the onset of disease. Apparently, once the virus reaches certain vital centres in the brain illness and death rapidly follow. 


\section{TABLE}

Concentration of Herpesvirus suis in various tissues of two squirrel monkeys that died 7 days after intranasal infection

\begin{tabular}{|c|c|c|}
\hline \multirow{2}{*}{ Tissue } & \multicolumn{2}{|c|}{$\begin{array}{l}\text { Concentration }(\log 10 \text { TCD50 } \\
\text { per } g) \text { in the stated tissue of }\end{array}$} \\
\hline & monkey no. 1 & monkey no. 2 \\
\hline $\begin{array}{l}\text { Caudate nucleus } \\
\text { Thalamus } \\
\text { Medulla } \\
\text { Cervical cord } \\
\text { Submandibular lymph-node } \\
\text { Nasal mucosa }\end{array}$ & $\begin{array}{l}4 \cdot 8 \\
3 \cdot 4 \\
4 \cdot 5 \\
5 \cdot 6 \\
5 \cdot 6 \\
4 \cdot 2\end{array}$ & $\begin{array}{l}4 \cdot 5 \\
3 \cdot 3 \\
4 \cdot 8 \\
3 \cdot 6 \\
4 \cdot 5\end{array}$ \\
\hline
\end{tabular}

Intermittent excretion of virus in saliva is a feature of natural B-virus infection of monkeys and is the reason for transmission of the virus to man by bites. However, although virus was present in the nasal mucosa of both squirrel monkeys at necropsy, only a single isolation was made from the nasal and oral swabs taken from monkeys examined during the first 10 days after infection. The monkey therefore resembles cattle and sheep in poor excretion of ADV into the nose and mouth, rather than the pig, which excretes high concentrations of virus for as long as 2 weeks (McFerran and Dow, 1964c).

The spread of ADV in rabbits, pigs and ruminants, like that of $B$ virus in monkeys (Keeble, Christofinis and Wood, 1958), is centripetally along the peripheral nerves from the infection site; after parenteral inoculation it travels to the dorsal root ganglia and the spinal cord (Hurst, 1933; McFerran and Dow, 1964a and b; Bergmann and Becker, 1967; McCracken, McFerran and Dow, 1973), and after intranasal or oral infection it passes along the olfactory, trigeminal, facial or glossopharyngeal nerves to their nuclei in the brain (McFerran and Dow, 1964a, $b$ and $c, 1965$ ). The distribution of the lesions in the present investigation indicates that ADV spreads similarly in monkeys. Involvement of the 7th and 9th cranial nuclei, which supply the salivary glands, was the probable cause of the characteristic salivation.

In general there was good correlation between the distribution of histological lesions and virus isolation in the brain, although the virus was obviously more widespread and present in higher concentration in the squirrel monkeys than in the grivets. In cattle and sheep, too, infection with ADV is always fatal, and lesions are restricted to certain parts of the brain; virus can also be isolated only from the nasal mucosa, pharynx or submandibular lymph nodes, even after oro-nasal infection (McFerran and Dow, 1964a and $b$ ).

The histological lesions in the brain closely resembled those found in Aujeszky's disease of pigs and ruminants (Dow and McFerran, 1962, 1964) and in H. hominis and B-virus encephalitides of man and monkeys (Sabin and Wright, 1934; Sabin and Hurst, 1935; Keeble et al., 1958; Pierce, Peirce and Hull, 1958; Davidson and Hummeler, 1960; Adams and Miller, 1973). The distribution of the lesions differed, however, from that described by Hurst (1933, 1936) and by Kersting and Kerekjarto (1959) in monkeys infected intracerebrally or into the sciatic nerve; in these, the inoculation of virus directly into the nervous system produced lesions predominantly in the cerebral cortex, hippocampus and medulla, while the brain stem, caudate nucleus and putamen were rarely affected. The same workers noted the absence of lesions in tissues other than the central nervous system and concluded that, in the monkey, ADV can attack only neural tissue. That this was also largely the case in the present study is particularly interesting, since the strain of ADV used has considerable affinity for the respiratory tract in the pig, growing to high titre and causing rhinitis and pneumonia (Baskerville et al., 1971; Baskerville, 1973). 


\section{SUMMARY}

Monkeys were infected intranasally with Herpesvirus suis. After an incubation period of 7 to 13 days the animals became acutely ill and rapidly died. Clinical signs included salivation, incoordination, ataxia and epileptiform convulsions, but not pruritus. Histopathological changes were confined to the central nervous system, and consisted of destruction of neurones with the formation of intranuclear inclusion bodies, gliosis and perivascular cuffing. Virus was isolated from the brain and spinal cord in the later stages of the illness but neutralising antibodies were not detected in serum. The distribution of lesions indicated direct spread of virus from the inoculation site along cranial nerves to the brain.

\section{REFERENCES}

Adams, H. AND Miller, D. 1973. Herpes simplex encephalitis: a clinical and pathological analysis of twenty-two cases. Post-grad. med. J., 49, 393.

BASKerville, A. 1973. The histopathology of experimental pneumonia in pigs produced by Aujeszky's disease virus. Res. vet. Sci., 14, 223.

Baskerville, A., McCracken, R. M. and McFerran, J. B. 1971. The histopathology of experimental rhinitis in pigs produced by a strain of Aujeszky's disease virus. Res. vet. Sci., 12, 323.

Bergmann, V. AND Becker, C. H. 1967. Untersuchungen zur Pathomorphologie und Pathogenese der Aujeszkyschen Krankheit. 2. Zur Histopathologie der Spinalganglien, Spinalnervenwürzeln und des Rückenmarks nach natürlicher und experimenteller Infektion beim Schwein. Pathologia vet., 4, 493.

Davidson, W. L. AND Hummeler, K. 1960. B virus infection in man. Ann. N.Y. Acad. Sci., 85, 970.

Dow, C. AND MCFerran, J. B. 1962. The neuropathology of Aujeszky's disease in the pig. Res. vet. Sci., 3, 436.

Dow, C. ANd McFerran, J. B. 1964. Experimental Aujeszky's disease in the sheep. Am.J. vet. Res., 25, 461.

HuRST, E. W. 1933. Studies on pseudorabies (infectious bulbar paralysis, mad itch). I. Histology of the disease, with a note on the symptomatology. J. exp. Med., 58, 415.

Hurst, E. W. 1936. Studies on pseudorabies (infectious bulbar paralysis, mad itch). III. The disease in the rhesus monkey, Macaca mulatta. J. exp. Med., 63, 449.

Jentzsch, K. D. AND Wigand, R. 1969. Zur Frage der Empfänglichkeit des Menschen für das Herpesvirus suis (Aujeszky-virus). 2. Antigenetische Beziehungen zwischen Herpesvirus suis und Herpesvirus simplex. Z. ges. Hyg., 15, 184.

Jentzsch, K. D. AND ApostolofF, E. 1970. Zur Frage der Empfänglichkeit des Menschen für das Herpesvirus suis (Aujeszky-virus). 4. Serologische Ermittlungen bei Personen infektionsgefährdeter Berufsgruppen. Z. ges. Hyg., 16, 692.

KeEble, S. A., Christofinis, G. J. AND Wood, W. 1958. Natural virus-B infection in rhesus monkeys. J. Path. Bact., 67, 189.

Kersting, G. AND Kerekjarto, B. von 1959. Zur experimentellen Pathologie der Aujeszkyschen Krankheit und der B-Virusinfektion (unter besonderer Berücksichtigung der primären Parenchymläsion). Arch. exp. VetMed., 13, 308.

McCracken, R. M., McFerran, J. B. and Dow, C. 1973. The neural spread of pseudorabies virus in calves. J. gen. Virol., 20, 17.

McFerran, J. B. AND Dow, C. 1964a. Virus studies on experimental Aujeszky's disease in calves. J. comp. Path., 74, 173.

McFerran, J. B. AND Dow, C. 1964b. The distribution of the virus of Aujeszky's disease in experimentally infected sheep. Res. vet. Sci., $5,143$.

McFerran, J. B. AND Dow, C. 1964c. The excretion of Aujeszky's disease virus by experimentally-infected pigs. Res. vet. Sci., 5, 405.

McFerran, J. B. AND Dow, C. 1965. The distribution of the virus of Aujeszky's disease (pseudorabies virus) in experimentally infected swine. Am. J. vet. Res., 26, 631.

J. MED. MICROBIOL.-VOL. 10 (1977) 
Pierce, E. C., Peirce, J. D. And Hull, R. N. 1958. B-virus: its current significance. Description and diagnosis of a fatal human infection. Am.J. Hyg., 68, 242.

SABIN, A. B. 1934. Studies on the B virus. Br. J. exp. Path., 15, 248.

SABIN, A. B. AND WRIGHT, A. M. 1934. Acute ascending myelitis following a monkey bite with isolation of a virus capable of reproducing the disease. J. exp. Med., 59, 115.

SABIN, A. B. AND Hurst, E. W. 1935. Studies on the B virus. IV. Histopathology of the experimental disease in rhesus monkeys and rabbits. Br.J. exp. Path., 16, 133.

Watson, D. H., Wildy, P., Harvey, B. A. M. and Shedden, W. I. H. 1967. Serological relationships among viruses of the herpes group. J. gen. Virol., 1, 139. 
Plate IX

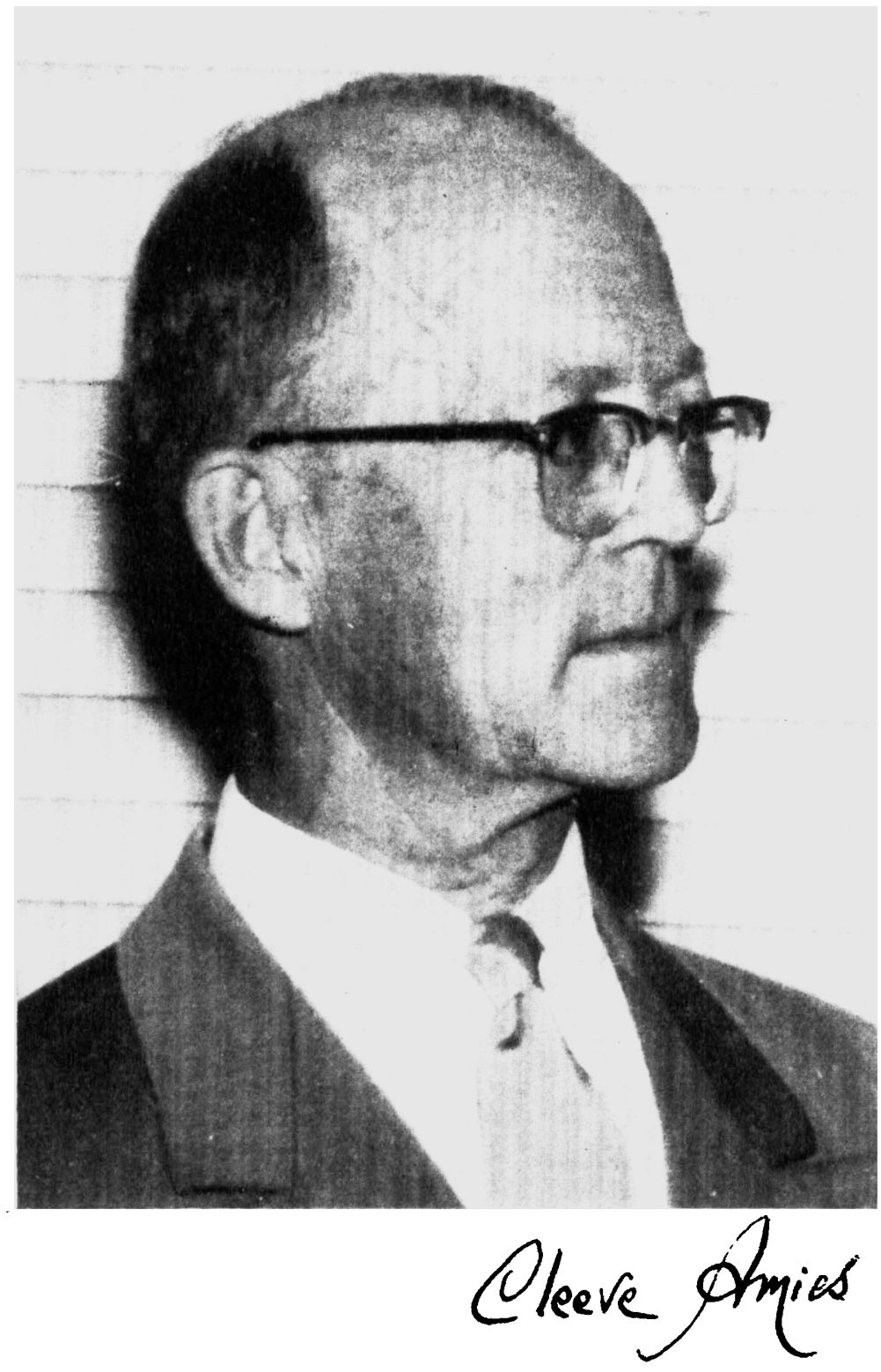

